\title{
Effect of the salts of deep ocean water on the production of cordycepin and adenosine of Cordyceps militaris-fermented product
}

\author{
Yu-Ping Hung ${ }^{1}$, Jyh-Jye Wang ${ }^{2}$, Bai-Luh Wei ${ }^{1}$ and Chun-Lin Lee ${ }^{1^{*}}$
}

\begin{abstract}
Cordyceps militaris is a type of entomogenous fungi and has been widely used as a medicinal fungus in Asia. Cordycepin produced by C. militaris has also been found to protect the liver. Moreover, deep ocean water (DOW) was proven to increase the functional compounds of functional fungi-fermented products. However, the regulation of the metals in DOW is still unclear. Therefore, this study investigated the effect of DOW and certain major ions on the production of cordycepin and adenosine of C. militaris. The results indicated that, compared with using ultra-pure water (UPW), using DOW to cultivate C. militaris in a submerged culture increases the production of biomass and adenosine $(p<0.05)$. In the results of solid culture, the concentration of DOW exhibits a dose effect on cordycepin production. DOW contains ions that can improve the effectiveness of cordycepin, such as $\mathrm{Mg}^{2+}, \mathrm{Na}^{+}, \mathrm{Ca}^{2+}, \mathrm{Fe}^{2+}$, and $\mathrm{NO}_{3}{ }^{-}$, whereas the ion $\mathrm{Cl}^{-}$features an inhibitory effect. Moreover, $\mathrm{Mg}^{2+}, \mathrm{Na}^{+}, \mathrm{K}^{+}, \mathrm{Ca}^{2+}, \mathrm{Fe}^{2+}$, and $\mathrm{SO}_{4}{ }^{2-}$ can increase the production of adenosine, whereas $\mathrm{Cl}^{-}$cannot. However, the synthetic water made from various types of sodium salts $\left(\mathrm{MgCl}_{2}, \mathrm{NaCl}, \mathrm{KCl}, \mathrm{CaCl}_{2}, \mathrm{FeCl}_{2}\right.$ ) had nearly the same effect on cordycepin production as that of DOW.
\end{abstract}

Keywords: Cordyceps militaris, Deep ocean water, lons, Cordycepin, Adenosine

\section{Introduction}

Deep ocean water (DOW) is characterized by low temperature, cleanness, and affluent production of inorganic nutrients and minerals. In recent years, because of its medicinal value, DOW has been extensively studied. Previous studies have noted that DOW has several health benefits, such as mitigating skin inflammation (Hataguchi et al. 2005), lowering blood lipids (Miyamura et al. 2004), reducing blood sugar (Hwang et al. 2009a), and reducing obesity (Hwang et al. 2009b). Moreover, DOW can be used to increase production of functional ingredients of microorganisms (Lee 2015). Studies have found that DOW can increase the functional ingredient production of monascin and ankaflavin of red mold dioscorea as well as triterpenoids, polysaccharide, and flavonoids of Antrodia camphorata (Lee et al. 2011; Wang et al. 2013a). Red

\footnotetext{
*Correspondence: cllee@nttu.edu.tw

${ }^{1}$ Department of Life Science, National Taitung University, 369, Sec. 2,

University Rd., Taitung 950, Taiwan, ROC

Full list of author information is available at the end of the article
}

mold dioscorea cultured by DOW lowers blood lipids and obesity more than that cultured by reverse osmosis water (ROW) and ultra-pure water (UPW) (Lee et al. 2011; Wang et al. 2013b). Moreover, compared with $A$. camphorata cultured by ROW, A. camphorata cultured by DOW protects the liver more effectively (Wang et al. 2013a). However, functional ions and the effects of ions in DOW on the growth and metabolites production of the functional fungi are still unclear incurrent. It should be an important topic for the application of DOW in future.

Recently, Cordyceps militaris has been regarded as an alternative to Ophiocordyceps sinensis. C. militaris has a similar functional composition to that of $O$. sinensis (Wang and Yao 2011). C. militaris also has antioxidant (Yu et al. 2006), antiinflammatory (Won and Park 2005), and antitumor effects (Yoo et al. 2004) as well as enhances sexual performance (Chang et al. 2008). According to relevant studies, the activity levels of the essential amino acids, cordycepin, Cordyceps polysaccharide, and superoxide

\section{Springer}


dismutase of artificially cultured C. militaris are all higher than those of wild O. sinensis (Dong et al. 2012).

This study used C. militaris BCRC 32219 as the testing strain and focused on solid culture to examine how various culture mediums and concentrations of DOW affect the production of adenosine and cordycepin of C. militaris. This study also analyzed the effect of the major ions in DOW on the production of adenosine and cordycepin of $C$. militaris by adding only one single type of salt.

\section{Materials and methods Chemicals}

Yeast mold (YM) agar and broth were purchased from Difco Laboratories Co. (Detroit, MI, USA). Magnesium, sodium, potassium, calcium, zinc and iron standard solutions were purchased from Showa Chemical Co. (Tokyo, Japan). Ethanol (95 \%) was purchased from Taiwan Tobacco and Liquor Co. (Taipei, Taiwan). The other chemicals purchased from Sigma Chemical Co. (St. Louis, MO, USA).

\section{The preparation of DOW, SW, and various salts water}

The concentrated DOW purchased from the Taiwan Yes Deep Ocean Water Co. (Hualien, Taiwan) was pumped from a depth of $670 \mathrm{~m}$ in the Pacific Ocean near the Eastern Taiwan and processed though the electrodeionization. According to our previous study, DOW including $20.65 \mathrm{mg} / \mathrm{L} \mathrm{Mg}^{2+}$ was defined as onefold DSW (Wang et al. 2013a). In this study, 30-fold DOW (including $619.5 \mathrm{mg} / \mathrm{L} \mathrm{Mg}^{2+}$ ) was prepared by the dilution of concentrated DOW (including 43,400 $\mathrm{mg} / \mathrm{L} \mathrm{Mg}^{2+}$ ) with UPW. The concentrations of the trace elements and minerals in 30X DOW included $619.5 \mathrm{mg} / \mathrm{L} \mathrm{Mg}^{2+}$, $327 \mathrm{mg} / \mathrm{L} \mathrm{Na}^{+}, 132 \mathrm{mg} / \mathrm{L} \mathrm{K}^{+}, 5.13 \mathrm{mg} / \mathrm{L} \mathrm{Ca}^{2+}, 8.55 \mu \mathrm{g} / \mathrm{L}$ $\mathrm{Fe}^{2+}, 1.156 \mathrm{mg} / \mathrm{L}$ nitrate, $649 \mathrm{mg} / \mathrm{L}$ sulfate, and $1.898 \mathrm{~g} / \mathrm{L}$ chloride.

In the preparation of the various metals salts solution, $\mathrm{Mg}\left(\mathrm{NO}_{3}\right)_{2}, \mathrm{NaCl}, \mathrm{KCl}, \mathrm{CaCO}_{3}$, and $\left(\mathrm{NH}_{4}\right)_{2} \mathrm{Fe}\left(\mathrm{SO}_{4}\right)_{2}$ solution were prepared according to the equal $\mathrm{Mg}^{2+}, \mathrm{Na}^{+}$, $\mathrm{K}^{+}, \mathrm{Ca}^{2+}, \mathrm{Fe}^{2+}$ concentrations in 10X-DOW, respectively. The five salts solutions were further mixed for the preparation of the synthetic water of mixed salts (Salt-SW). In the preparation of the sodium salts solution, $\mathrm{NaNO}_{3}$, $\mathrm{Na}_{2} \mathrm{SO}_{4}, \mathrm{Na}_{3} \mathrm{PO}_{4}$ and $\mathrm{NaCl}$ solutions were prepared according to equal $\mathrm{SO}_{4}{ }^{2-}, \mathrm{PO}_{4}{ }^{3-}, \mathrm{NO}_{3}{ }^{-}$, and $\mathrm{Cl}^{-}$concentration in $30 \mathrm{X}$ or $60 \mathrm{X}$ DOW, respectively. These four sodium salts solutions were mixed for the preparation of a synthetic water of mixed sodium salts $(\mathrm{Na}-\mathrm{SW})$. In the preparation of the nitrate salts solution $\mathrm{Mg}\left(\mathrm{NO}_{3}\right)_{2}$, $\mathrm{NaNO}_{3}, \mathrm{KNO}_{3}, \mathrm{Ca}\left(\mathrm{NO}_{3}\right)_{2}, \mathrm{Fe}\left(\mathrm{NO}_{3}\right)_{2} \cdot 6 \mathrm{H}_{2} \mathrm{O}$ solutions were prepared according to equal $\mathrm{Mg}^{2+}, \mathrm{Na}^{+}, \mathrm{K}^{+}, \mathrm{Ca}^{2+}$, and $\mathrm{Fe}^{2+}$ concentrations in 30X DOW, respectively. In the preparation of the chloride salts solutions, $\mathrm{MgCl}_{2}$,
$\mathrm{NaCl}, \mathrm{KCl}, \mathrm{CaCl}_{2}, \mathrm{FeCl}_{2}$ solutions were prepared according to equal $\mathrm{Mg}^{2+}, \mathrm{Na}^{+}, \mathrm{K}^{+}, \mathrm{Ca}^{2+}$, and $\mathrm{Fe}^{2+}$ concentrations in 30X DOW, respectively. These five chloride salts solutions were further mixed for the preparation of a synthetic water of mixed chloride salts (Cl-SW).

\section{Microorganism and seed cultures}

C. militaris BCRC 32219 was purchased from the Bioresource Collection and Research Center (Hsinchu, Taiwan). C. militaris was maintained on YM agar at $24{ }^{\circ} \mathrm{C}$ and transferred to fresh medium for 10 days intervals. Seed cultures were prepared by transferring a loopful of colony from YM agar slant into a 500-mL Hinton flask containing $100 \mathrm{~mL}$ medium $(3 \mathrm{~g} / \mathrm{L}$ yeast extract, $5 \mathrm{~g} / \mathrm{L}$ malt extract, $10 \mathrm{~g} / \mathrm{L}$ peptone, $3 \mathrm{~g} / \mathrm{L}$ dextrose). The cultures were incubated at $28{ }^{\circ} \mathrm{C}$ and $100 \mathrm{rpm}$ for 5 days. After that, inoculum sizes $5 \%$ was transferred to submerged or solid cultured substrate.

\section{Submerged fermentation of C. militaris in DOW or UPW}

Submerged fermentation was carried out using a 500$\mathrm{mL}$ Hinton flask containing $100-\mathrm{mL}$ medium $(3 \mathrm{~g} / \mathrm{L}$ yeast extract, $5 \mathrm{~g} / \mathrm{L}$ malt extract, $10 \mathrm{~g} / \mathrm{L}$ peptone, $3 \mathrm{~g} / \mathrm{L}$ dextrose in UPW or DOW). The cultures were incubated at $28^{\circ} \mathrm{C}$ for 5 days at $100 \mathrm{rpm}$. After submerged culture, mycelium and filtrate were separated using filter paper. The mycelium was dried by freeze dryer and then weighted. The dried mycelium powder and fresh filtrate was analyzed for intracellular and extracellular $\beta-1,3$ glucan, respectively.

\section{Solid fermentation of $C$. militaris in DOW or ROW}

Thirty grams oat substrates was soaked in $30 \mathrm{~mL}$ UPW, DOW, SW, or various salts water, and then was autoclaved for $20 \mathrm{~min}$ at $121^{\circ} \mathrm{C}$ in a 500 -mL glass bottle. After being cooled, the substrate was inoculated with a $10 \%$ $(\mathrm{v} / \mathrm{w})$ seed culture medium. The inoculated substrate was cultured at $24{ }^{\circ} \mathrm{C}$ for 20 days in a dark incubator. After dark culture, C. militaris was then cultured at $14{ }^{\circ} \mathrm{C}$ under a $12 \mathrm{~h}$ light:12 h dark cycle (light on at 6:00) for 60 days. After fermentation, the crushed and dried product was used for the experiments.

\section{Determination of $\beta-1,3$ glucan}

The selective aniline blue reaction was employed to detect the existence of $\beta-1,3$ glucan. The method described by the previous studies (Wood and Fulcher 1984; Young and Jacobs 1998) were followed with some modifications. The sample was dissolve with $0.3 \mathrm{~N} \mathrm{NaOH}$ and stirred at ambient temperature for completely dissolve. The $\mathrm{pH}$ of the sample solution was then adjusted to $11.5 \pm 0.1$ by adding $1 \mathrm{~N} \mathrm{HCl}$ and the volume was made to $10 \mathrm{~mL}$ using $\mathrm{Na}_{2} \mathrm{HPO}_{4}-\mathrm{NaOH}$ buffer (pH 11.5 
containing $0.5 \mathrm{M} \mathrm{NaCl}$ ). A $0.2 \mathrm{~mL}$ of sample was reacted with $0.1 \mathrm{~mL}$ aniline blue $(1 \mathrm{mg} / \mathrm{mL})$ for $2 \mathrm{~h}$ at ambient temperature. The excitation and emission wavelength were set at 395 and $495 \mathrm{~nm}$, respectively.

\section{Determination of cordycepin and adenosine}

The powder of $C$. militaris-fermented product $(0.1 \mathrm{~g})$ was extracted respectively with $1 \mathrm{~mL}$ of methanol at $50{ }^{\circ} \mathrm{C}$ for $1 \mathrm{~h}$. The extracts $(10 \%, \mathrm{w} / \mathrm{v})$ were further filtered with $0.45 \mu \mathrm{m}$ pore size filter and analyzed by HPLC (Model L-2130, Hitachi Co., Tokyo, Japan) on a $\mathrm{C}_{18}$ column $\left(25 \mathrm{~cm} \times 4.6 \mathrm{~mm}\right.$ i.d., $5 \mu \mathrm{m}$, Luna ${ }^{\circledR}$, Phenomenex, Torrance, CA, USA) using the gradient elution. HPLC was performed according to the method described previously (Yu et al. 2007) in triplicate. Cordycepin and adenosine were separated by gradient elution using the mobile phase with the composition of water-methanol (95.0/5.0 to $58.4 / 41.6$ in $20 \mathrm{~min}, \mathrm{v} / \mathrm{v})$. The flow rate was set at $0.8 \mathrm{~mL} / \mathrm{min}$. Cordycepin and adenosine were detected using a photodiode array detector (Model L-2455 DAD, Hitachi Co.) set at $260 \mathrm{~nm}$ and full wavelength.

\section{Statistical analysis}

Data are expressed as mean \pm standard deviation. Analysis of variance by Duncan's test and Pearson's productmoment correlation coefficient test were determined using SPSS version 10.0 software (SPSS Institute, Inc., Chicago, IL, USA). Differences with $p<0.05$ were considered statistically significant.

\section{Results}

Effect of deep ocean water on the production of mycelium and certain functional ingredients under submerged culture

This study investigated the effect of DOW on the production of $C$. militaris mycelium and certain functional ingredients of $C$. militaris under submerged culture. As presented in Table 1, compared with ultrapure water (UPW), DOW enhanced the production of C. militaris mycelium by $23 \%(p<0.05)$, which significantly increased the production of adenosine by $18 \%$ $(p<0.05)$. However, DOW did not significantly affect the production of intracellular and extracellular $\beta$-1,3-glucan $(p>0.05)$. Moreover, under the submerged culture, the experimental results of this study revealed that no cordycepin was produced in the fermentative liquid and mycelium of UPW and DOW.

\section{Effect of various deep ocean water concentrations on production of cordycepin and adenosine in Cordyceps militaris-fermented products}

Cordycepin cannot be produced by cultivating C. militaris in submerged culture. Therefore, this study focused on solid culture and explored the effect of various factors on production of the functional ingredients of $C$. militaris. For this phase, the DOW of various concentrations was used as the water source for C. militaris-fermented production. The effect of DOW on the production of adenosine and cordycepin was also analyzed. Figure 1a shows that after 60 days' fermentation, the C. militaris-fermented products with UPW, 10X-DOW, or 20X-DOW sources had increased cordycepin production; however, the increase was lower than that of the $C$. militaris-fermented products with the 30X-DOW source. When the fermentation was extended to 80 days, the $C$. militarisfermented product with the 30X-DOW source had the highest cordycepin production. This cordycepin production was higher than that of the 20X-DOW, 10X-DOW, and UPW sources by $22 \%(p<0.01), 26 \%(p<0.01)$, and $64 \%(p<0.01)$, respectively, displaying a dose effect.

Figure $1 \mathrm{~b}$ presents the production state of adenosine. When DOW of various concentrations was used as the water source for $C$. militaris-fermented production, the production of adenosine at various time points did not differ significantly $(p>0.05)$.

\section{Effect of the major metal ions of deep ocean water} on production of cordycepin and adenosine of Cordyceps militaris-fermented products

DOW is rich in the concentration of $\mathrm{Mg}^{2+}, \mathrm{Na}^{+}, \mathrm{K}^{+}$, $\mathrm{Ca}^{2+}, \mathrm{Zn}^{2+}$, and $\mathrm{Fe}^{2+}$, which is possible to enhance the production of the functional metabolites. Therefore, the effect of the major metal ions in DOW on the production of cordycepin and adenosine were further analyzed

Table 1 Effect of DOW on the biomass, cordycepin, adenosine, intracellular $\beta-1,3-$ glucan, and extracellular $\beta$-1,3-glucan production of $C$. militaris in submerged culture

\begin{tabular}{|c|c|c|c|c|c|}
\hline & Biomass (g) & Cordycepin $(\mathrm{mg} / \mathrm{g})$ & Adenosine (mg/g) & Intracellular $\beta-1,3-$ glucan (mg/g) & Extracellular $\beta-1,3$-glucan (mg/mL) \\
\hline UPW & $0.57 \pm 0.07$ & $-^{\mathrm{a}}$ & $1.77 \pm 0.16$ & $13.35 \pm 2.38$ & $0.020 \pm 0.004$ \\
\hline DOW & $0.70 \pm 0.02^{*}$ & $-{ }^{a}$ & $2.08 \pm 0.09^{*}$ & $15.83 \pm 2.06$ & $0.021 \pm 0.001$ \\
\hline
\end{tabular}

Data are presented as mean \pm SD $(n=3)$.

* Indicated the significant difference $(p<0.05)$ as compared with UPW.

a Under detection limit. 

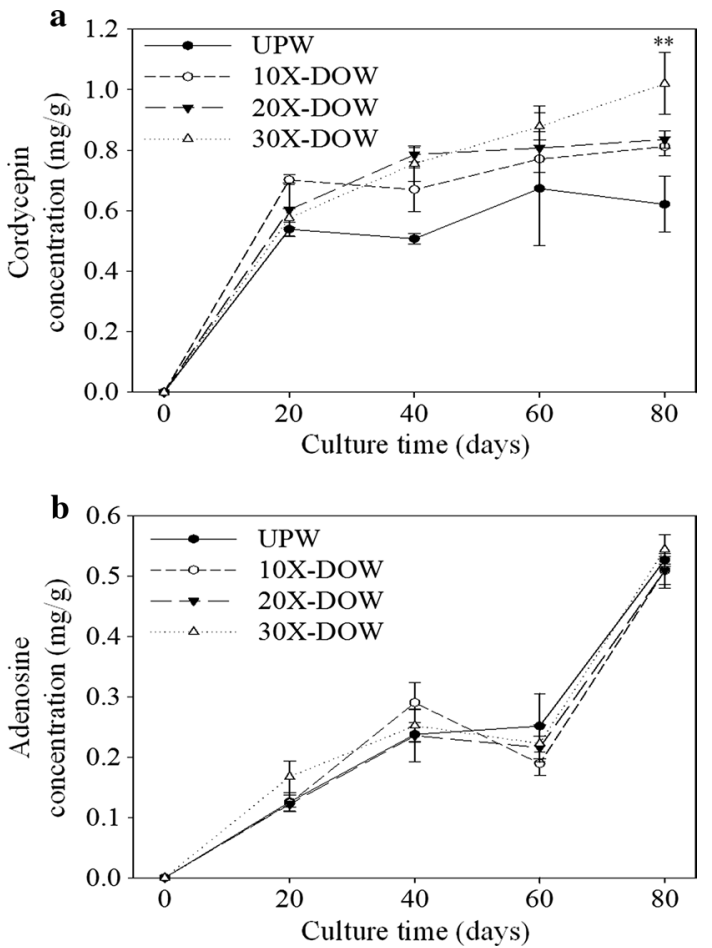

Fig. 1 Effect of various concentration of DOW on the cordycepin (a) and adenosine (b) production of C. militaris-fermented oats in solid culture. Data are presented as mean $\pm S D(n=3) .{ }^{* *}$ indicated the significant difference $(p<0.01)$ as compared with UPW.

in this study. Figure 2a shows the effect of DOW, Salt$\mathrm{SW}$, and various salts solution on cordycepin production. The concentration of $\mathrm{Mg}^{2+}, \mathrm{Na}^{+}, \mathrm{K}^{+}, \mathrm{Ca}^{2+}, \mathrm{Fe}^{2+}$ in $\mathrm{Mg}\left(\mathrm{NO}_{3}\right)_{2}, \mathrm{NaCl}, \mathrm{KCl}, \mathrm{CaCO}_{3}$, and $\left(\mathrm{NH}_{4}\right)_{2} \mathrm{Fe}\left(\mathrm{SO}_{4}\right)_{2}$ were equal to that in 10X-DOW, respectively. The five salts solutions were mixed for the preparation of 10X-Salt-SW. As shown, 10X-DOW, 10X-Salt-SW, and $\mathrm{Mg}\left(\mathrm{NO}_{3}\right)_{2}$ solution promoted the production of cordycepin $(p<0.05)$. However, compared with the production of cordycepin in the UPW group, the $\mathrm{NaCl}$ solution reduced the production of cordycepin by $57 \%$ and had a suppressive effect $(p<0.001)$. The effect of $\mathrm{KCl}, \mathrm{CaCO}_{3}$, and $\left(\mathrm{NH}_{4}\right)_{2} \mathrm{Fe}\left(\mathrm{SO}_{4}\right)_{2}$ solutions were not significant $(p>0.05)$. Moreover, the effects of DOW, Salt-SW, and various salts solution on the production of adenosine are presented in Fig. 2b. 10X-DOW and 10X-Salt-SW enhanced the production of adenosine $(p<0.05)$. Among the salts solution, only $\left(\mathrm{NH}_{4}\right)_{2} \mathrm{Fe}\left(\mathrm{SO}_{4}\right)_{2}$ solutions promoted the production of adenosine $(p<0.05)$.

\section{Effect of various sodium salts on production of cordycepin} and adenosine of Cordyceps militaris-fermented products According to above results (Fig. $2 \mathrm{a}$ ), $\mathrm{NaCl}$ solution significantly suppressed the production of cordycepin. This
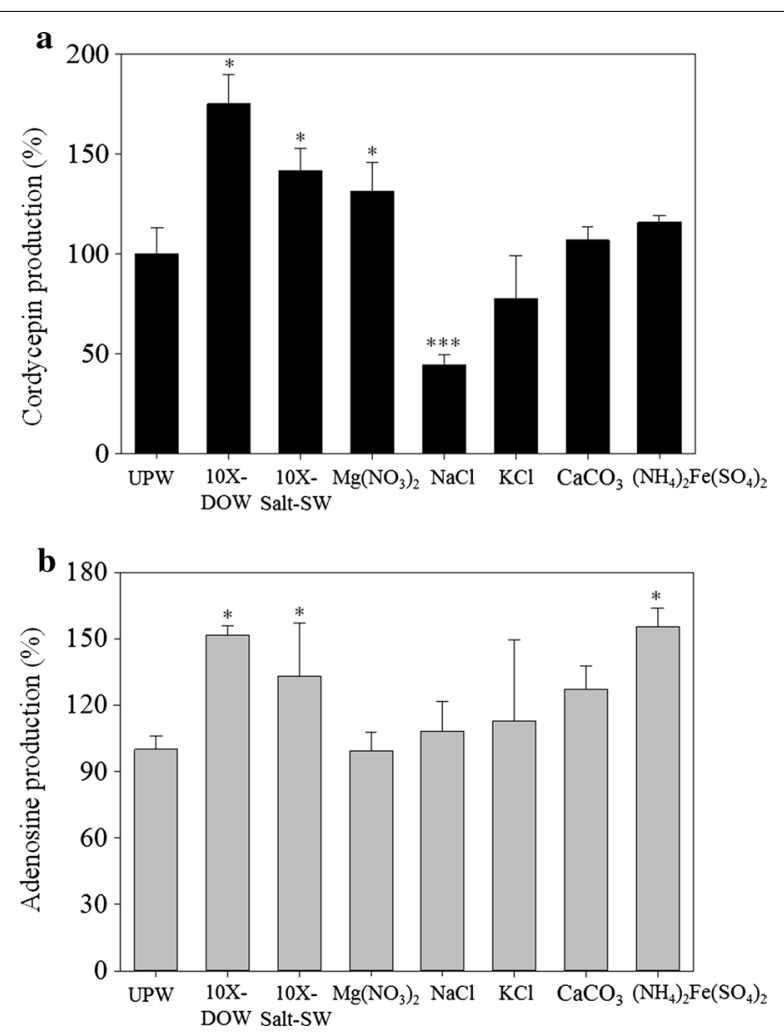

Fig. 2 Effect of major metal ions in DOW on the cordycepin (a) and adenosine (b) production of C. militaris-fermented oats in solid culture. The concentration of $\mathrm{Mg}^{2+}, \mathrm{Na}^{+}, \mathrm{K}^{+}, \mathrm{Ca}^{2+}, \mathrm{Fe}^{2+}$ in $\mathrm{Mg}\left(\mathrm{NO}_{3}\right)_{2}$, $\mathrm{NaCl}, \mathrm{KCl}, \mathrm{CaCO}_{3}$, and $\left(\mathrm{NH}_{4}\right)_{2} \mathrm{Fe}\left(\mathrm{SO}_{4}\right)_{2}$ were equal to that in 10X-DOW, respectively. Salt-SW was a mixture of the five salt solutions. Data are presented as mean $\pm \mathrm{SD}(\mathrm{n}=3) .{ }^{*}, * * *$ indicated the significant difference ( $p<0.05, p<0.001$, respectively) as compared with UPW.

section further discusses the effect of various sodium salts on production of cordycepin and adenosine. According to the comparison in Fig. 3, at the 30-fold sodium salt concentration, DOW, Na-SW, $\mathrm{NaNO}_{3}, \mathrm{Na}_{2} \mathrm{SO}_{4}, \mathrm{Na}_{3} \mathrm{PO}_{4}$, and $\mathrm{NaCl}$, the $C$. militaris-fermented products with the DOW source and $\mathrm{NaNO}_{3}$ respectively had 52 and $46 \%$ higher cordycepin production than the $C$. militarisfermented products with UPW $(p<0.01)$. However, after fermentation, $\mathrm{NaCl}$ increased cordycepin production by $58 \%(p<0.001)$. Moreover, DOW, Na-SW, and $\mathrm{NaNO}_{3}$ enhanced adenosine production by 60,74 , and $104 \%(p<0.05)$, respectively. Nevertheless, the selection of DOW, $\mathrm{Na}_{2} \mathrm{SO}_{4}, \mathrm{Na}_{3} \mathrm{PO}_{4}$, and $\mathrm{NaCl}$ did not affect the production of adenosine. At a concentration of 60-fold, the DOW, Na-SW, $\mathrm{NaNO}_{3}, \mathrm{Na}_{2} \mathrm{SO}_{4}$, and $\mathrm{Na}_{3} \mathrm{PO}_{4}$ groups exhibited a decline in cordycepin production. However, in contrast to the UPW group, the $\mathrm{NaCl}$ group showed a significant $70 \%$ decrease in the production of cordycepin $(p<0.001)$. Furthermore, DOW and $\mathrm{Na}_{2} \mathrm{SO}_{4}$ increased adenosine production $(p<0.05)$, whereas adenosine production decreased in the other groups. 

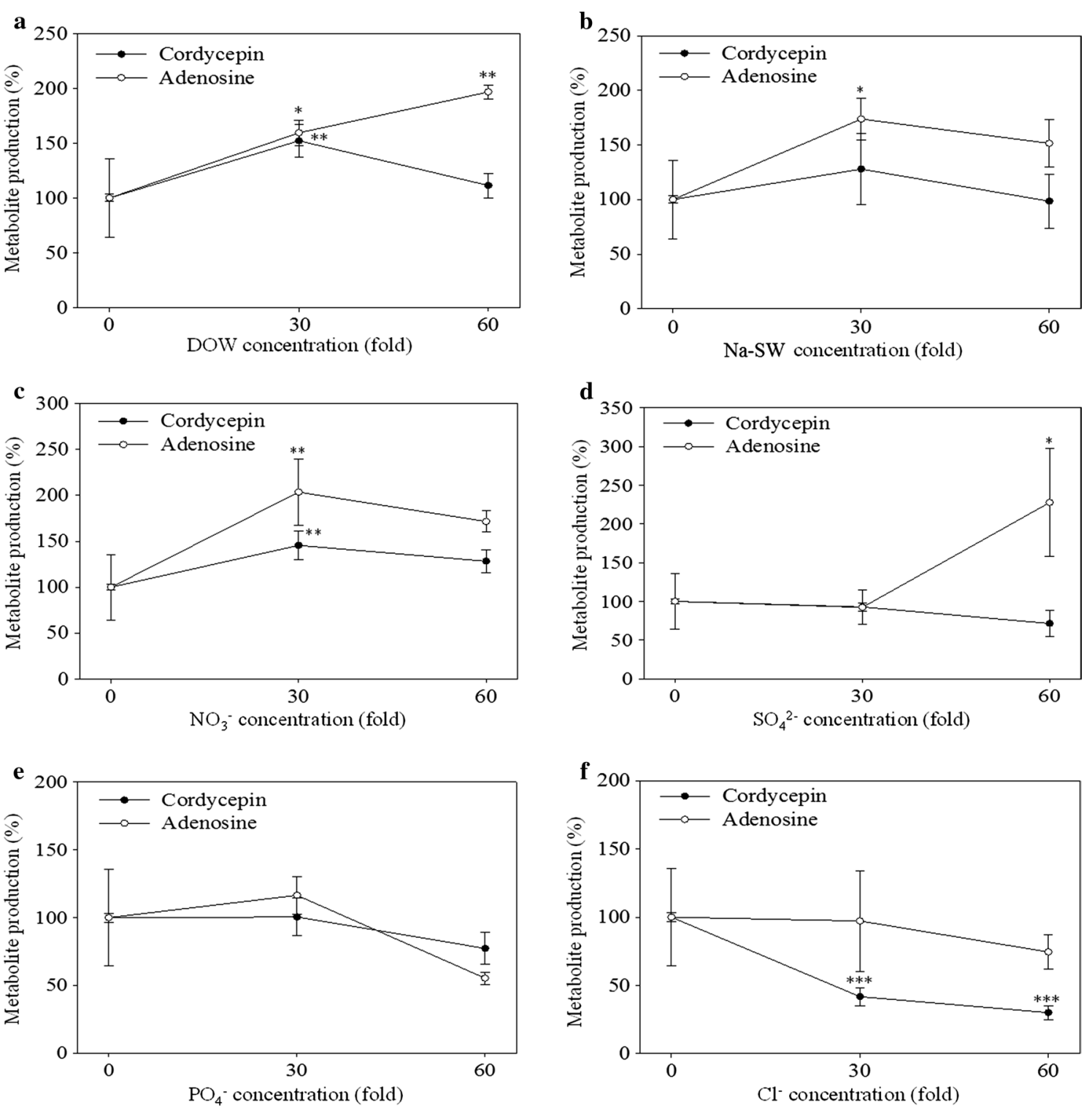

Fig. 3 Effect of various sodium salt ions on the cordycepin and adenosine production of C. militaris-fermented oats in solid culture. DOW (a), Na-SW (b), $\mathrm{NaNO}_{3}(\mathbf{c}), \mathrm{Na}_{2} \mathrm{SO}_{4}(\mathbf{d}), \mathrm{Na}_{3} \mathrm{PO}_{4}(\mathbf{e})$, or $\mathrm{NaCl}(\mathbf{f})$ solution was added to the solid substrate of $\mathrm{C}$. militaris during solid culture, respectively. $\mathrm{NaNO}_{3}$, $\mathrm{Na}_{2} \mathrm{SO}_{4}, \mathrm{Na}_{3} \mathrm{PO}_{4}$ and $\mathrm{NaCl}$ solution included equal $\mathrm{SO}_{4}{ }^{2-}, \mathrm{PO}_{4}{ }^{3-}, \mathrm{NO}_{3}{ }^{-}$, and $\mathrm{Cl}^{-}$concentration to that in $30 \mathrm{X}$ or $60 \mathrm{X}$ DOW, respectively. Na-SW was a mixture of the four sodium salt solutions. Data are presented as mean $\pm \mathrm{SD}(\mathrm{n}=3) .{ }^{*},{ }^{* *}$, ${ }^{* *}$ indicated the significant difference $(p<0.05, p<0.01$, $p<0.001$, respectively) as compared with UPW.

Effect of various nitrate salts on production of cordycepin and adenosine in Cordyceps militaris-fermented products

As shown in Fig. 3, at the 30-fold sodium salt concentration, only $\mathrm{NaNO}_{3}$ could enhance cordycepin and adenosine production. Therefore, this section focuses on the concentration of $\mathrm{NaNO}_{3}$ and discusses the effect of various combinations of nitrate salts on the production of cordycepin and adenosine. The 30X concentration of $\mathrm{Mg}^{2+}, \mathrm{Na}^{+}, \mathrm{K}^{+}, \mathrm{Ca}^{2+}, \mathrm{Fe}^{2+}$ in $\mathrm{Mg}\left(\mathrm{NO}_{3}\right)_{2}, \mathrm{NaNO}_{3}, \mathrm{KNO}_{3}$,
$\mathrm{Ca}\left(\mathrm{NO}_{3}\right)_{2}, \mathrm{Fe}\left(\mathrm{NO}_{3}\right)_{2} \cdot 6 \mathrm{H}_{2} \mathrm{O}$ were equal to that in $30 \mathrm{X}$ DOW. According to Fig. 4a, DOW, $\mathrm{Mg}\left(\mathrm{NO}_{3}\right)_{2}, \mathrm{NaNO}_{3}$, $\mathrm{Ca}\left(\mathrm{NO}_{3}\right)_{2}$, and $\mathrm{Fe}\left(\mathrm{NO}_{3}\right)_{2}$ had significantly increased cordycepin production $(p<0.01)$. However, $\mathrm{KNO}_{3}$ did not exhibit such an increase $(p<0.05)$. Moreover, Fig. $4 \mathrm{~b}$ illustrates that $\mathrm{Mg}\left(\mathrm{NO}_{3}\right)_{2}, \mathrm{NaNO}_{3}, \mathrm{KNO}_{3}, \mathrm{Ca}\left(\mathrm{NO}_{3}\right)_{2}$, and $\mathrm{Fe}\left(\mathrm{NO}_{3}\right)_{2}$ significantly increased adenosine production $(p<0.001)$, whereas 30X-DOW moderately increased adenosine production $(p<0.05)$. 
Effect of various chloride salts on production of cordycepin and adenosine in Cordyceps militaris-fermented products

Figure 4 illustrates that at the 30-fold sodium salt concentration, $\mathrm{NaNO}_{3}$ enhanced cordycepin production, but $\mathrm{Na}_{2} \mathrm{SO}_{4}$ and $\mathrm{NaPO}_{4}$ did not enhance cordycepin production. However, $\mathrm{NaCl}$ significantly reduced cordycepin production $(p<0.001)$. Therefore, this section uses solutions with equal metal ion concentrations to that in 30X-DOW to discuss the effect of various chloride salts on production of cordycepin and adenosine. As shown in Fig. $5 \mathrm{a}, \mathrm{MgCl}_{2}, \mathrm{NaCl}$, and $\mathrm{KCl}$ significantly reduced cordycepin production $(p<0.05)$, and cordycepin production in the $\mathrm{CaCl}_{2}$ and $\mathrm{FeCl}_{2}$ solutions declined. The Cl-SW solution produced by combining all five chloride salts significantly reduced cordycepin production $(p<0.05)$.

The adenosine production results are shown in Fig. $5 \mathrm{~b}$. DOW and Cl-SW enhanced the production of adenosine $(p<0.05)$. Furthermore, $\mathrm{MgCl}_{2}, \mathrm{NaCl}, \mathrm{KCl}$, and $\mathrm{FeCl}_{2}$ significantly enhanced the production of adenosine
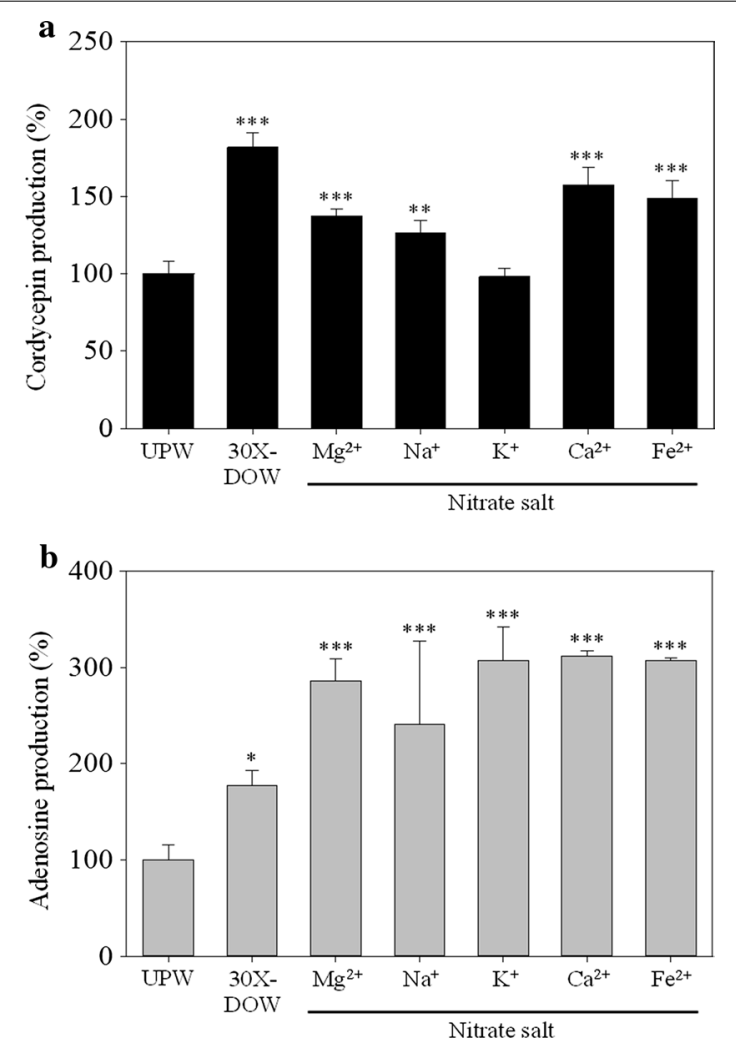

Fig. 4 Effect of various nitrate salts on the cordycepin (a) and adenosine (b) production of $C$. militaris-fermented oats in solid culture. The $30 X$ concentration of $\mathrm{Mg}^{2+}, \mathrm{Na}^{+}, \mathrm{K}^{+}, \mathrm{Ca}^{2+}, \mathrm{Fe}^{2+}$ in $\mathrm{Mg}\left(\mathrm{NO}_{3}\right)_{2}, \mathrm{NaNO}_{3}$, $\mathrm{KNO}_{3}, \mathrm{Ca}\left(\mathrm{NO}_{3}\right)_{2}, \mathrm{Fe}\left(\mathrm{NO}_{3}\right)_{2} \cdot 6 \mathrm{H}_{2} \mathrm{O}$ were equal to that in $30 \mathrm{X}-\mathrm{DOW}$. Data are presented as mean $\pm \mathrm{SD}(\mathrm{n}=3) .^{*},{ }^{* *},{ }^{* *}$ indicated the significant difference ( $p<0.05, p<0.01, p<0.001$, respectively) as compared with UPW.
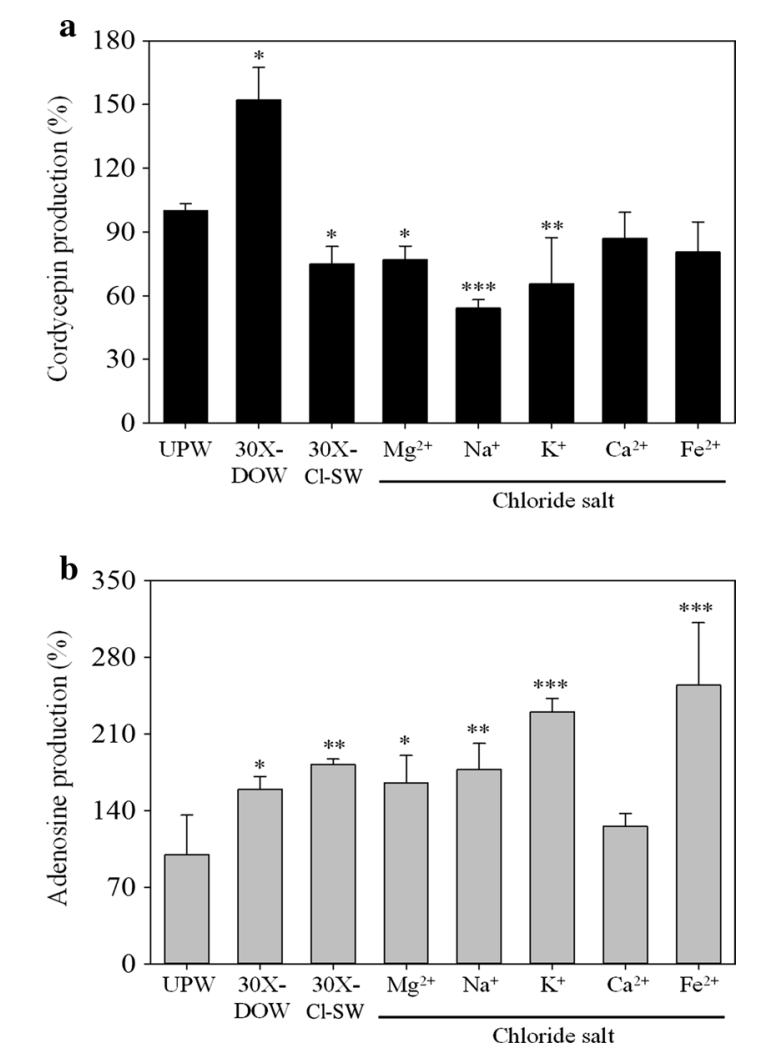

Fig. 5 Effect of various chloride salts on the cordycepin (a) and adenosine (b) production of C. militaris-fermented product in solid culture. The $30 \mathrm{X}$ concentration of $\mathrm{Mg}^{2+}, \mathrm{Na}^{+}, \mathrm{K}^{+}, \mathrm{Ca}^{2+}, \mathrm{Fe}^{2+}$ in $\mathrm{MgCl}_{2}, \mathrm{NaCl}$, $\mathrm{KCl}, \mathrm{CaCl}_{2}, \mathrm{FeCl}_{2}$ were equal to that in 30X-DOW. Cl-SW was a mixture of the five chloride salt solutions. Data are presented as mean \pm SD $(n=3) .{ }^{*},{ }^{* *},{ }^{* *}$ indicated the significant difference $(p<0.05, p<0.01$, $p<0.001$, respectively) as compared with UPW.

( $p<0.05)$, whereas $\mathrm{CaCl}_{2}$ had no significant effect on adenosine production $(p<0.05)$. However, Cl-SW enhanced adenosine production $(p<0.05)$.

\section{Discussion}

As confirmed in previous studies, DOW can enhance production of the functional ingredients of red mold dioscorea such as monascin and ankaflavin as well as reduce the production of hepatotoxin, nephrotoxin, and citrinin (Lee et al. 2011). DOW can also promote production of $A$. camphorata mycelium as well as increase production of the functional ingredients of triterpenoids, polysaccharide, and flavonoids (Wang et al. 2013a). This study focuses on submerged culture to investigate the effect of DOW on production of $C$. militaris mycelium and the functional ingredients of $C$. militaris. Table 1 demonstrates that DOW promoted the production of $C$. militaris mycelium more than UPW did and significantly increased the production of adenosine $(p<0.05)$. This result agrees with those of previous studies except for 
DOW significantly affecting the production of intracellular and extracellular $\beta$-1,3-glucan $(p<0.05)$, a phenomenon that was not observed in this study.

Moreover, this study addressed the effect of DOW of various concentrations on the production of cordycepin and adenosine in C. militaris-fermented products. In this study, cordycepin production increased as the concentration of DOW increased. The content of cordycepin in the 30X-DOW solution reached the highest point on the 80th day of fermentation $(p<0.01)$. The DOW of various concentrations did not significantly enhance the production of adenosine $(p>0.05)$. The results were compared with the SW results. $\mathrm{Mg}\left(\mathrm{NO}_{3}\right)_{2}$ promoted cordycepin production $(p<0.05), \mathrm{NaCl}$ significantly suppressed cordycepin production $(p<0.001)$, and $\mathrm{KCl}$ reduced cordycepin production. However, $\mathrm{NaCl}$ and $\mathrm{KCl}$ had $\mathrm{Cl}^{-}$, whereas $\mathrm{CaCO}_{3}$ and $\left(\mathrm{NH}_{4}\right)_{2} \mathrm{Fe}\left(\mathrm{SO}_{4}\right)_{2}$ had no significant effect on cordycepin production $(p>0.05)$. Furthermore, SW can increase cordycepin production to a degree similar to that of DOW. $\left(\mathrm{NH}_{4}\right)_{2} \mathrm{Fe}\left(\mathrm{SO}_{4}\right)_{2}$ increases adenosine production $(p<0.05)$. However, the other four salt solution did not have this effect $(p>0.05)$. SW can also increase adenosine production to a degree similar to that of DOW.

The results illustrated that all the metal ions in DOW can either increase or not affect cordycepin production. However, the production of cordycepin in $\mathrm{NaCl}$ solution significantly decreases after fermentation. $\mathrm{Na}^{+}$constitutes a large proportion of DOW. This study compared the effects of DOW and various sodium salt solutions with concentrations equal to that of DOW on the production of cordycepin and adenosine. At the 30 -fold sodium salt concentration, $\mathrm{NO}_{3}{ }^{-}$increased the production of cordycepin $(p<0.01)$ and adenosine $(p<0.05)$ the most; however, it had no effect on adenosine production. $\mathrm{SO}_{4}{ }^{2-}$ and $\mathrm{PO}_{4}{ }^{-}$had no effect on the production of cordycepin and adenosine. SW did not significantly increase cordycepin production but significantly increased the production of adenosine $(p<0.05)$. At the 60 -fold sodium salt concentration, the production of cordycepin and adenosine with $\mathrm{SW}, \mathrm{NO}_{3}{ }^{-}$, and $\mathrm{PO}_{4}{ }^{-}$decreased. At this concentration, the cordycepin production with $\mathrm{SO}_{4}{ }^{2-}$ declined as well, but the adenosine production increased significantly $(p<0.05)$. Concurrently, $\mathrm{Cl}^{-}$of the 60 -fold concentration significantly reduced cordycepin production $(p<0.001)$. The $\mathrm{NO}_{3}{ }^{-}$, $\mathrm{SO}_{4}{ }^{2-}, \mathrm{PO}_{4}{ }^{-}$, and $\mathrm{Cl}^{-}$used in this study refer to sodium salts. The $\mathrm{NaCl}$ solution reduced cordycepin production, whereas the $\mathrm{NaNO}_{3}$ solution increased cordycepin production. Therefore, we conclude that $\mathrm{NO}_{3}{ }^{-}$can increase cordycepin production, that $\mathrm{Cl}^{-}$may reduce cordycepin production, and that $\mathrm{NaCl}$ solution has no effect on adenosine production. Nevertheless, the $\mathrm{NaNO}_{3}$ solution promoted adenosine production. At the 60 -fold sodium salt concentration, only the $\mathrm{Na}_{2} \mathrm{SO}_{4}$ solution enhanced adenosine production. Therefore, $\mathrm{NO}_{3}{ }^{-}$and $\mathrm{SO}_{4}{ }^{2-}$ may enhance adenosine production, whereas $\mathrm{Cl}^{-}$does not affect adenosine production.

Regarding to the effect of nitrates of various compositions on the production of cordycepin and adenosine (Fig. 4), $\mathrm{Mg}\left(\mathrm{NO}_{3}\right)_{2}, \mathrm{NaNO}_{3}, \mathrm{Ca}\left(\mathrm{NO}_{3}\right)_{2}$, and $\mathrm{Fe}\left(\mathrm{NO}_{3}\right)_{2}$ significantly increased cordycepin production $(p<0.01)$. However, $\mathrm{NaNO}_{3}$ did not have this effect $(p>0.05)$. $\mathrm{Mg}\left(\mathrm{NO}_{3}\right)_{2}, \mathrm{NaNO}_{3}, \mathrm{KCl}, \mathrm{Ca}\left(\mathrm{NO}_{3}\right)_{2}$, and $\mathrm{Fe}\left(\mathrm{NO}_{3}\right)_{2}$ significantly increases adenosine production $(p<0.001)$. Because equal amounts of $\mathrm{NO}_{3}{ }^{-}$produces equal effects, $\mathrm{Mg}^{2+}, \mathrm{Na}^{+}, \mathrm{Ca}^{2+}$, and $\mathrm{Fe}^{2+}$ are estimated to be primarily responsible for increasing production of cordycepin and adenosine. In addition, $\mathrm{K}^{+}$is likely to significantly increase adenosine production.

According to Fig. $5 \mathrm{Cl}^{-}$can suppress cordycepin production. This study used various chloride salts to investigate the effect of metal ions on the production of cordycepin and adenosine. All the chloride salts, $\mathrm{MgCl}_{2}$, $\mathrm{NaCl}$, and $\mathrm{KCl}$ significantly reduced cordycepin production $(p<0.05)$. Furthermore, $\mathrm{CaCl}_{2}$ and $\mathrm{FeCl}_{2}$ reduced cordycepin production. Therefore, the SW composed of the five chloride salts significantly reduced cordycepin production $(p<0.05)$. Furthermore, $\mathrm{MgCl}_{2}, \mathrm{NaCl}, \mathrm{KCl}$, and $\mathrm{FeCl}_{2}$ significantly increased adenosine production $(p<0.05)$. However, $\mathrm{CaCl}_{2}$ did not increase adenosine production $(p>0.05)$. SW increased adenosine production $(p<0.05)$. The addition of $\mathrm{Mg}\left(\mathrm{NO}_{3}\right)_{2}, \mathrm{NaNO}_{3}$, $\mathrm{KNO}_{3}, \mathrm{Ca}\left(\mathrm{NO}_{3}\right)_{2}$, or $\mathrm{Fe}\left(\mathrm{NO}_{3}\right)_{2}$ can significantly enhance cordycepin production. However, in all the chloride salts, $\mathrm{MgCl}_{2}, \mathrm{NaCl}, \mathrm{KCl}, \mathrm{CaCl}_{2}$, and $\mathrm{FeCl}_{2}$ either significantly reduced cordycepin production or caused a declining trend in cordycepin production. Therefore, $\mathrm{Cl}^{-}$might contribute to reducing cordycepin production in C. militaris-fermented products.

The effect of SW on the production of cordycepin and adenosine varied depending on the combination of sodium salts. As shown in Fig. 3, Na-SW composed of various sodium salts had no significant effect on cordycepin production but enhanced adenosine production. The increase of cordycepin production might have been attributed to $\mathrm{NaNO}_{3}$. Moreover, $\mathrm{NaCl}$ suppressed the production of cordycepin, and the effect of $\mathrm{Na}_{2} \mathrm{SO}_{4}$ and $\mathrm{NaPO}_{4}$ on cordycepin production was not significant. Therefore, the combined effect of the four sodium salts rendered the resultant $\mathrm{Na}$-SW least effective for promoting cordycepin production. Moreover, $\mathrm{NaNO}_{3}$ enhanced adenosine production, whereas $\mathrm{Na}_{2} \mathrm{SO}_{4}, \mathrm{NaPO}_{4}$, and $\mathrm{NaCl}$ had no effect on adenosine production. Hence, the combination of these four sodium salts resulted in the Na-SW that significantly promoted adenosine 
production. Figure $5 \mathrm{a}, \mathrm{b}$ show that the $\mathrm{Cl}-\mathrm{SW}$ of various combinations of chloride salts suppressed cordycepin production and promoted adenosine production. This $\mathrm{Cl}-\mathrm{SW}$ effect might have occurred because $\mathrm{MgCl}_{2}, \mathrm{NaCl}$, and $\mathrm{KCl}$ were all active in suppressing cordycepin production, and $\mathrm{CaCl}_{2}$ and $\mathrm{FeCl}_{2}$ were not significantly associated with cordycepin production. Therefore, the $\mathrm{Cl}-\mathrm{SW}$ comprising the five chloride salts reduced cordycepin production. Moreover, except for $\mathrm{CaCl}_{2}$, the other chloride salts increased adenosine production. Therefore, the $\mathrm{Cl}-\mathrm{SW}$ increased adenosine production. As confirmed in Figs. 2 and 5 demonstrate that Salt-SW increased the production of cordycepin and adenosine, and the $\mathrm{Mg}\left(\mathrm{NO}_{3}\right)_{2}$ sodium salt should be the functional salt for increasing the production of cordycepin and adenosine. The results of fermentation in various chloride salt mediums revealed that $\mathrm{NaCl}$ and $\mathrm{KCl}$ suppressed cordycepin production but enhanced adenosine production. This result is verified in Fig. $5 \mathrm{a}$, b. However, $\mathrm{CaCO}_{3}$ and $\left(\mathrm{NH}_{4}\right)_{2} \mathrm{Fe}\left(\mathrm{SO}_{4}\right)_{2}$ least enhanced cordycepin production, whereas $\left(\mathrm{NH}_{4}\right)_{2} \mathrm{Fe}\left(\mathrm{SO}_{4}\right)_{2}$ increased adenosine production (Fig. 2). Figure 4a, b imply that $\mathrm{Ca}^{2+}$ and $\mathrm{Fe}^{2+}$ are likely to enhance the production of cordycepin and adenosine. Hence, the Salt-SW comprising $\mathrm{Mg}\left(\mathrm{NO}_{3}\right)_{2}$, $\mathrm{NaCl}, \mathrm{KCl}, \mathrm{CaCO}_{3}$, and $\left(\mathrm{NH}_{4}\right)_{2} \mathrm{Fe}\left(\mathrm{SO}_{4}\right)_{2}$ enhanced production of cordycepin and adenosine. Furthermore, SaltSW produced by combining sodium and chloride salts increased adenosine production to the same extent that DOW did. However, the Na-SW comprising only sodium salts increased cordycepin production to nearly the same extent that DOW did.

The study by Cui and Zhang (2012) noted that the addition of $\mathrm{Mg}^{2+}$ and $\mathrm{Mn}^{2+}$ in the cultivation of C. militaris in submerged culture significantly promoted $C$. militaris mycelium and extracellular polysaccharide production. Moreover, adding sodium selenite into the solid culture mediums for C. militaris cultivation significantly increased the production of cordycepin, cordyceps acid, cordyceps polysaccharide, and organic selenium of the C. militaris fruit body compared with the control group that had no sodium selenite. This production increase was proportional to the concentration of sodium selenite (Dong et al. 2012). The addition of $10 \mathrm{mM} \mathrm{Ca}^{2+}$ in Ganoderma liquid culture mediums can significantly increase the production of Ganoderma acid (Xu and Zhong 2012). In summary, compared with UPW, DOW can more effectively promote the growth of $C$. militaris mycelium and enhance the production of cordycepin, its functional ingredient. Moreover, the concentration of DOW has a dose effect on cordycepin production. The enhancing effect of DOW on cordycepin production is mainly attributed to its ions such as $\mathrm{Mg}^{2+}, \mathrm{Na}^{+}, \mathrm{Ca}^{2+}, \mathrm{Fe}^{2+}$, and
$\mathrm{NO}_{3}{ }^{-}$. However, the $\mathrm{Cl}^{-}$in DOW suppresses cordycepin production. For adenosine, $\mathrm{Mg}^{2+}, \mathrm{Na}^{+}, \mathrm{K}^{+}, \mathrm{Ca}^{2+}, \mathrm{Fe}^{2+}$ and $\mathrm{SO}_{4}{ }^{2-}$ have the ability of increasing its production, but such an ability is not observed for $\mathrm{Cl}^{-}$. Furthermore, the DOW ions can increase cordycepin production. This ability might be induced by the pressure of the C. militaris growth environment, which forces $C$. militaris to enter the secondary metabolic phase and begin producing secondary metabolites. This ability could stem from ions in DOW that serve as enzyme or protein cofactors in cultivating C. militaris and produce cordycepin to promote the growth of mycelium and production of the functional ingredients of $C$. militaris. The effect of $\mathrm{Na}-\mathrm{SW}$ on the production of cordycepin and adenosine varies depending on the combination of sodium salts. Therefore, the production of cordycepin can be increased by adding nitrates and reducing the production of $\mathrm{Cl}^{-}$in DOW. Moreover, chloride salts, nitrates, and $\mathrm{SO}_{4}{ }^{2-}$ can be added to DOW to increase adenosine production.

This study employed DOW to cultivate $C$. militaris in submerged and solid culture and investigated the effect of DOW on the production of C. militaris' fermentative products, namely cordycepin and adenosine. The results demonstrated that using 30X-DOW as a water source to produce $C$. militaris-fermented products can significantly increase the production of cordycepin. This cordycepin production is $65 \%$ higher than the $C$. militaris-fermented products of the UPW water solution $(p<0.001)$. The concentration of DOW also has a dose effect on cordycepin production. Moreover, the $\mathrm{Mg}^{2+}, \mathrm{Na}^{+}, \mathrm{Ca}^{2+}, \mathrm{Fe}^{2+}$, and $\mathrm{NO}_{3}{ }^{-}$in DOW increase cordycepin production; however, the $\mathrm{Cl}^{-}$in DOW exhibits an opposite effect. $\mathrm{Mg}^{2+}, \mathrm{Na}^{+}$, $\mathrm{K}^{+}, \mathrm{Ca}^{2+}, \mathrm{Fe}^{2+}$, and $\mathrm{SO}_{4}{ }^{2-}$ can increase adenosine production, but $\mathrm{Cl}^{-}$cannot. The Cl-SW containing $\mathrm{MgCl}_{2}$, $\mathrm{NaCl}, \mathrm{KCl}, \mathrm{CaCl}_{2}, \mathrm{FeCl}_{2}$ can not only increase adenosine production but also promote cordycepin production to nearly the same extent that DOW does.

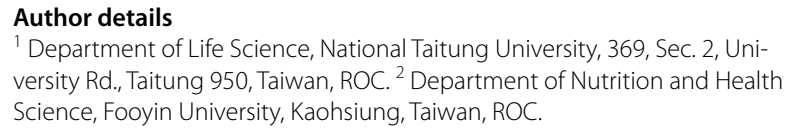

Acknowledgements

This study was supported by a grant from the National Science Council, R.O.C. (NSC 101-2313-B-143-003-MY3) and Ministry of Economic Affairs, R.O.C. (103-EC-17-A-32-S1-230).

\section{Competing interests}

The authors declare that they have no competing interests.

\section{Ethical statement}

This article does not contain any studies with human participants or animals performed by any of the authors.

Received: 30 July 2015 Accepted: 2 August 2015

Published online: 14 August 2015 


\section{References}

Chang Y, Jeng KC, Huang KF, Lee YC, Hou CW, Chen KH et al (2008) Effect of Cordyceps militaris supplementation on sperm production, sperm motility and hormones in Spraque-Dawley rats. Am J Chin Med 36:849-859. doi:10.1142/S0192415X08006296

Cui JD, Zhang YN (2012) Evaluation of metal ions and surfactants effect on cell growth and exopolysaccharide production in two-stage submerged culture of Cordyceps militaris. Appl Biochem Biotechnol 168:1394-1404

Dong JZ, Lei C, Ai XR, Wang Y (2012) Selenium enrichment on Cordyceps militaris link and analysis on its main active components. Appl Biochem Biotechnol 166:1215-1224. doi:10.1007/s12010-011-9506-6

Hataguchi Y, Tai H, Nakajima H, Kimata H (2005) Drinking deep-sea water restores mineral imbalance in atopic eczema/dermatitis syndrome. Eur 」 Clin Nutr 59:1093-1096. doi:10.1038/sj.ejcn.1602218

Hwang HS, Kim HA, Lee SH, Yun JW (2009a) Anti-obesity and antidiabetic effects of deep sea water on ob/ob mice. Mar Biotechnol (NY) 11:531539. doi:10.1007/s10126-008-9171-0

Hwang HS, Kim SH, Yoo YG, Chu YS, Shon YH, Nam KS et al (2009b) Inhibitory effect of deep-sea water on differentiation of 3T3-L1 adipocytes. Mar Biotechnol (NY) 11:161-168. doi:10.1007/s10126-008-9131-8

Lee CL (2015) The advantages of deep ocean water for the development of functional fermentation food. Appl Microbiol Biotechnol 99:2523-2531. doi:10.1007/s00253-015-6430-7

Lee CL, Kung YH, Wang JJ, Lung TY, Pan TM (2011) Enhanced hypolipidemic effect and safety of red mold dioscorea cultured in deep ocean water. J Agric Food Chem 59:8199-8207. doi:10.1021/jf201948v

Miyamura M, Yoshioka S, Hamada A, Takuma D, Yokota J, Kusunose M et al (2004) Difference between deep seawater and surface seawater in the preventive effect of atherosclerosis. Biol Pharm Bull 27:1784-1787

Wang XL, Yao YJ (2011) Host insect species of Ophiocordyceps sinensis: a review. Zookeys 127:43-59. doi:10.3897/zookeys.127.802

Wang LC, Kuo IU, Tsai TY, Lee CL (2013a) Antrodia camphorata-fermented product cultured in deep ocean water has more liver protection against thioacetamide-induced fibrosis. Appl Microbiol Biotechnol 97:9955-9967. doi:10.1007/s00253-013-5214-1

Wang LC, Lung TY, Kung YH, Wang JJ, Tsai TY, Wei BL et al (2013b) Enhanced anti-obesity activities of red mold dioscorea when fermented using deep ocean water as the culture water. Mar Drugs 11:3902-3925. doi:10.3390/ md11103902

Won SY, Park EH (2005) Anti-inflammatory and related pharmacological activities of cultured mycelia and fruiting bodies of Cordyceps militaris. J Ethnopharmacol 96:555-561. doi:10.1016/j.jep.2004.10.009

Wood PJ, Fulcher RG (1984) Specific interaction of aniline blue with $(1 \rightarrow 3)-\beta$-D-glucan. Carbohydr Polym 4:49-72

Xu YN, Zhong JJ (2012) Impacts of calcium signal transduction on the fermentation production of antitumor ganoderic acids by medicinal mushroom Ganoderma lucidum. Biotechnol Adv 30:1301-1308. doi:10.1016/j. biotechadv.2011.10.001

Yoo HS, Shin JW, Cho JH, Son CG, Lee YW, Park SY et al (2004) Effects of Cordyceps militaris extract on angiogenesis and tumor growth. Acta Pharmacol Sin 25:657-665

Young S, Jacobs RR (1998) Sodium hydroxide-induced conformational change in schizophyllan detected by the fluorescence dye, aniline blue. Carbohydr Res 310:91-99

Yu HM, Wang BS, Huang SC, Duh PD (2006) Comparison of protective effects between cultured Cordyceps militaris and natural Cordyceps sinensis against oxidative damage. J Agric Food Chem 54:3132-3138. doi:10.1021/ jf053111w

Yu R, Ye B, Yan C, Song L, Zhang Z, Yang W, Zhao Y (2007) Fingerprint analysis of fruiting bodies of cultured Cordyceps militaris by high-performance liquid chromatography-photodiode array detection. J Pharm Biomed Anal 44:818-823

\section{Submit your manuscript to a SpringerOpen ${ }^{\circ}$ journal and benefit from:}

- Convenient online submission

- Rigorous peer review

- Immediate publication on acceptance

- Open access: articles freely available online

- High visibility within the field

- Retaining the copyright to your article

Submit your next manuscript at $\boldsymbol{~ s p r i n g e r o p e n . c o m ~}$ 